\title{
Effect of Storage Time on Nutrient, Biodeteriorating Fungi and Aflatoxin Contents of Bitter Leaf (Vernonia amygadalina) and JUTE (Corchorus olitorius)
}

Jonathan Segun G, Onile Olanrewaju G, Asemoloye Michael D* and Omotayo Omolola 0

Department of Botany, Mycology/Biotechnology Unit, University of Ibadan, Nigeria

\begin{abstract}
Unhygienic handlings of several African food products during storage have been reported to promote fungal biodeterioration and subsequent aflatoxin contamination. Therefore, this study was aimed to investigate the effect of storage time on nutrient, commonly associated bio-deteriorating fungi and aflatoxin contents of selected vegetables; Bitter leaf (Vernonia amygdalina) and Jute (Corchorus olitorius) in Nigeria. Fresh and stored vegetable samples (24) were collected from different markets in Ibadan, Nigeria, they were analyzed for proximate (\% Moisture, Carbohydrate, Crude Protein, Fat and Fibre), nutrient (Potassium, Calcium, Phosphorus, Sodium Iron, Zinc and Magnesium), fungal and aflatoxin contents (AFB $, A F B_{2}, A F G_{1}$ and $A F G_{2}$ ). Most dominantly associated fungal strains were identified as Aspergillus niger, Aspergillus flavus, Aspergillus terreus, Aspergillus tamari, Aspergillus parasiticus, Aspergillus fumigatus, Penicillium chrysogenum and Rhizopus nigricans. The fungal incidence was more pronounced in the stored samples as compared to the fresh samples. The storage time also significantly affected the nutrient and aflatoxin contents of the vegetables; most nutrients decreased with increasing storage period while the aflatoxin contents increased. The study affirms that the storage time has effect on the nutrient, fungal contamination and consequently on the associated aflatoxin, although the detected aflatoxin levels were below the tolerance limit but these may increase with the storage time. It is therefore advisable to take hygienic measures during storage period and also, prolong storage should be discouraged.
\end{abstract}

Keywords: Unhygienic handling; Storage time; Fungal biodeterioration, Nutrient composition, Aflatoxins, Health implications

\section{Introduction}

Fungal contaminations of foods and feeds is currently raising global food safety concerns due to their ability to colonize food items, either causing physical damage or release some toxic secondary metabolites commonly known as 'Mycotoxins' [1]. The most commonly identified mycotoxin in African foods and feeds is 'Aflatoxin (AF)', $\mathrm{AF}$ is produced by fungi of the genera Aspergillus, there are four major aflatoxins; $\mathrm{AFB}_{1}, \mathrm{AFB}_{2}, \mathrm{AFG}_{1}$ and $\mathrm{AFG}_{2}$ due to their high prevalence in nature and toxicity [2]. AF has been established to be powerful carcinogenic, cytotoxic, mutagenic and teratogenic substances to human [3]. Most susceptible food stuffs for the aflatoxin contamination are corn, barley; wheat, coffee beans, peanuts, spices, herbs, some raw or processed fruits and vegetables. In Nigeria, Aflatoxins have been reported in yam chips, tomatoes and pawpaw [4-14]. However, there are limited reports on vegetables either in fresh or stored forms in Nigeria.

Vegetables are readily used either in fresh or dried forms, some dried leaves are preferably eaten in some parts of Nigeria on daily basis. Fungal spoilage of vegetables can occur during storage, handling and transportation as well as market and unfortunately, vegetable products that are susceptible to fungi growth can also be contaminated with aflatoxins $[15,16]$. Drying is usually the practice for storing vegetables in Nigeria to make the products more durable and the bulk of it preserved so they may be available all year round. However, unhygienic handling of dried vegetable products may still make them susceptible to infestation with fungi and other contaminants.

Bitter leaf (Vernonia amygdalina) for example is a green shrub in family Asteraceae; it has petiole leaf of about $6 \mathrm{~mm}$ diameter and characteristic odor and bitter taste. Vernonia amgydalina grows under a range of ecological zones in Africa being drought tolerant and produces large fodder biomass for both human and animal nutrition $[17,18]$. Vernonia amygdalina plant is commonly found around homes in Southern Nigeria, it is commonly used as a green vegetable or spice especially in the popular 'bitter-leaf soup' also, it is widely used for both therapeutic and nutritional purposes [19]. Also, another common vegetable Nigeria is Jute (Corchorus olitorius L.); it belongs to the family Tiliaceae. Jute is a fiber crop and one of the popular tropical leafy vegetable in Africa, Asia and some parts of the Middle East and Latin America [20]. It is a common leafy vegetable in Cote d'Voire, Benin, Nigeria, Cameroon, Sudan, Kenya, Uganda and Zimbabwe [21]. It is popularly known as Ewedu in the Southwestern part of Nigeria, where the boiled and mashed fresh leaf is a delicacy and the mucilaginous leaves are consumed along with other staples. It is extremely consumed as a health vegetable, because it contains abundant $\beta$-carotene and other carotenoids, vitamins $\mathrm{B} 1, \mathrm{~B} 2, \mathrm{C}$ and $\mathrm{E}$, and minerals. The vegetable also has varying proportion of dietary fibre and protein required for health [22].

This research was therefore embarked upon to investigate the effect of storage time on the nutrient, associated biodeteriorating fungi and aflatoxin contents of fresh and dried Verlonia and jute vegetables.

\section{Materials and Methods}

\section{Collection of samples}

Freshly harvested healthy samples of Bitter leaf (Vernonia amygdalina) and Jute (Corchorus olitorius) were purchased in bulk from

*Corresponding author: Michael Dare A, Department of Botany, Mycology/ Biotechnology Unit, University of Ibadan, Nigeria, Tel: 2348064844977; E-mail: asemoloyemike@gmail.com

Received April 11, 2018; Accepted April 19, 2018; Published April 26, 2018

Citation: Segun GJ, Olanrewaju GO, Michael DA, Omolola OO (2018) Effect of Storage Time on Nutrient, Biodeteriorating Fungi and Aflatoxin Contents of Bitter Leaf (Vernonia amygadalina) and JUTE (Corchorus olitorius). J Microb Biochem Technol 10: 49-55. doi: 10.4172/1948-5948.1000395

Copyright: @ 2018 Segun GJ, et al. This is an open-access article distributed under the terms of the Creative Commons Attribution License, which permits unrestricted use, distribution, and reproduction in any medium, provided the original author and source are credited. 
Citation: Segun GJ, Olanrewaju GO, Michael DA, Omolola OO (2018) Effect of Storage Time on Nutrient, Biodeteriorating Fungi and Aflatoxin Contents of Bitter Leaf (Vernonia amygadalina) and JUTE (Corchorus olitorius). J Microb Biochem Technol 10: 49-55. doi: 10.4172/19485948.1000395

different markets in Nigeria as shown below:

i. Bodija market; $7.4351^{\prime} \mathrm{N}, 3.9143^{\prime} \mathrm{E}$

ii. Moniya market; $7.5249^{\prime} \mathrm{N} 3.9151^{\prime} \mathrm{E}$

iii. Oja Oba market; 7. $3739^{\prime} \mathrm{N}, 3.5720^{\prime} \mathrm{E}$

They were collected in sterile polythene bags and labeled according to time and location; they were then taken to the Pathology/Mycology Laboratory of Department of Botany, University of Ibadan for further studies.

\section{Sample preparation}

The leaf samples were removed from their stalks, sliced and divided into two halves. One half was air dried, labeled and stored for respective months till when desired. The other half was immediately analyzed for fungal isolation, nutrient and aflatoxin compositions.

\section{Isolation and characterization of fungi biota}

The isolation of fungi was carried out according to procedure described by all samples collected were conditioned in a sterile package [23]. About two grams of each of the samples taken at random were aseptically placed in three replicates of Petri-dishes containing Potato Dextrose Agar and Lactic acid $\left(10.53 \mathrm{~g} \mathrm{~mL}^{-1}\right)$. The dishes were incubated at $27 \pm 2^{\circ} \mathrm{C}$ for 3-6 days. Fungal cultures obtained were subsequently sub-cultured for purification. Upon fungi maturation, they were characterized based on cultural and morphological features such as colony diameter, colony color on agar, front and reverse and colony texture. Slide culture was then prepared and incubation in moist chambers at $26 \pm 2^{\circ} \mathrm{C}$ for 4 days before observation under a light microscope (labomed, model CxL). Mycological keys and manuals were used for macro and microscopic features that are commonly used identification of fungi, which were conidiophores, conidial shape, phialides and metulae, presence and shape of vesicles [24].

\section{Aflatoxin extraction, detection and quantification}

Extraction: $1 \mathrm{~g}$ (of each sample) was pipetted into a $100 \mathrm{~mL}$ conical flask. $2.5 \mathrm{~mL}$ of distilled and $25 \mathrm{~mL}$ of chloroform water were added. The flask was covered with a stopper and shake in a shaker for $30 \mathrm{~min}$ after which the solution obtained was filter using a Whattman no. 1 filter paper. $10 \mathrm{~mL}$ of each extract or filtrate was collected and evaporated to dryness to a volume of $5 \mathrm{~mL}$ on a hot water bath. $5 \mathrm{~mL}$ extract was stored in dark bottles in a freezer for detection and quantification [25].

Detection of aflatoxin: $1 \mathrm{~mL}$ chloroform and $0.2 \mathrm{~mL}$ of the reconstituted extract was spotted on a precoated $20 \times 20 \mathrm{~cm}$ TLC plate along with aflatoxin standards of known concentration. The spotted TLC plate was developed in an equilibrated tank containing chloroform: acetone $(9: 1 \mathrm{v} / \mathrm{v})$. The developed TLC plate was air-dried at ambient temperature $\left(28 \pm 2^{\circ} \mathrm{C}\right)$ and aflatoxins were detected under UV light at wavelength of $360 \mathrm{~nm}$. A colour change from blue to yellow upon exposure to aqueous sulphuric acid $(50: 50 \mathrm{v} / \mathrm{v})$ confirmed the presence of Aflatoxin $B_{1}$. Aflatoxin $B_{2}$ was derived from Aflatoxin $B_{1}$ as dihydroderivative which experienced a colour change from pale blue to deep yellowish color upon exposure to aqueous sulphuric acid (50:50) to confirm its presence. Aflatoxin $G_{1}$ fluoresced yellowish green upon exposure to UV light while Aflatoxin $\mathrm{G}_{2}$ fluoresced pale yellowish green upon exposure to same UV light [25].

Quantification of aflatoxin: $0.5 \mu \mathrm{m}$ thick preparative TLC plates was employed for the quantitation of stored extract after aflatoxin extraction was applied to the plate as band rather than a spot to chromatograph, the maximum amount of sample at the same time. The preparative TLC plates were developed in an equilibrated tank as an aflatoxin extraction. When the solvent front had risen to about $3 / 4$ of the total length of the plate, the plate was taken out of the tank and examined under UV light. The area containing the toxin of interest was located and scrapped off, elute with chloroform and filter using Whattman No. 1 filter paper. The extract was evaporated to dryness over a hot water bath and reconstituted with $3 \mathrm{~mL}$ chloroform. The $3 \mathrm{~mL}$ reconstituted solution and aflatoxin standard of $20 \mu \mathrm{g} / \mathrm{mL}$ concentration was used to read Absorbance or Optical Density on an ultraviolet Spectrophotometer (Cecil Instrument CE505) at a wavelength of $360 \mathrm{~nm}$ [25]. Aflatoxin concentration in $\mu \mathrm{g} / \mathrm{kg}$ was calculated using the formula:

$\underline{\text { Absorbance of sample } \times \text { Conc. of standard } \times \text { Dil. factor }}$

Absorbance of standard

Crude protein determination: The crude protein in the samples was determined by the routine semi-micro Kjeldahl, procedure. $0.5 \mathrm{~g}$ of each finely ground dried sample was weighed carefully into the Kjeldahl digestion tubes, 1 tablet of selenium catalyst and $10 \mathrm{~mL}$ of conc. $\mathrm{H}_{2} \mathrm{SO}_{4}$ was added into the digestion preset at $500^{\circ} \mathrm{C}$. The digestion was left for $4 \mathrm{~h}$ in a fume cupboard. The tube was placed in a distilling unit and 5 $\mathrm{mL}$ of $40 \% \mathrm{NaOH}$ was added to it. The mixture was steam distilled for 2 min into a $50 \mathrm{~mL}$ flask containing $10 \mathrm{~mL}$ of $2 \%$ Boric acid, mixed with indicator solution which was then titrated against $0.01 \mathrm{~N} \mathrm{HCl}$ until a wine colour was obtained. The quantification was done using AOAC procedure [26].

Crude fat determination: $250 \mathrm{~cm}^{3}$ clean boiling flasks were dried in oven at $105-110^{\circ} \mathrm{C}$ for about $30 \mathrm{~min}$. It was later transferred into desiccator and allowed to cool. About $2 \mathrm{~g}$ of sample was weighed accurately into labeled thimbles. The correspondingly labeled cooled boiling flasks were weighed. The boiling flasks were filled with about $300 \mathrm{~cm}^{3}$ of petroleum ether (boiling point $40^{\circ} \mathrm{C}-60^{\circ} \mathrm{C}$ ). The extraction thimble was plugged with cotton wool. The soxhlet apparatus was assembled and allowed to reflux for about $6 \mathrm{~h}$. The thimble was removed with care and the petroleum ether was collected in the top of the container of the set-up and drained into a container for re-use. When the flask was almost free of petroleum ether it was removed and dried at $105^{\circ} \mathrm{C}-110^{\circ} \mathrm{C}$ for $1 \mathrm{~h}$. It was later transferred into a desiccator from the oven and allowed to cool and weighed [26].

$$
\% \text { Fat }=\frac{\text { Weight of fat }}{\text { Weight of sample }} \times 100
$$

Dry matter and moisture determination: $2 \mathrm{~g}$ of the sample were weighed into a previously weighed crucible $\left(\mathrm{W}_{0}\right)$. The crucible plus sample $\left(\mathrm{W}_{1}\right)$ taken was then transferred into the oven set at $100^{\circ} \mathrm{C}$ to dry to a constant weight for $2 \mathrm{~h}$. At the end, the crucible plus sample was removed from the oven and transferred to desiccator, cooled for 10 min and weighed $\left(\mathrm{W}_{3}\right)[26]$.

$$
\% \text { Dry Matter }(D M)=\frac{W_{3}-W_{0}}{W_{1}-W_{0}} \times 100
$$

$\%$ Moisture $=100-\%$ DM

Ash determination: $2 \mathrm{~g}$ of each sample was weighed into a porcelain crucible. This was transferred into the muffle furnace set at $550^{\circ} \mathrm{C}$ and left for about $4 \mathrm{~h}$. About this time it had turned to white ash. The crucible and its content were cooled to about $100^{\circ} \mathrm{C}$ in air, then room temperature in a desiccator and weighed [26].

$$
\text { Ash content }=\frac{\text { Weight of ash }}{\text { Original weight of sample }} \times 100
$$


Citation: Segun GJ, Olanrewaju GO, Michael DA, Omolola OO (2018) Effect of Storage Time on Nutrient, Biodeteriorating Fungi and Aflatoxin Contents of Bitter Leaf (Vernonia amygadalina) and JUTE (Corchorus olitorius). J Microb Biochem Technol 10: 49-55. doi: 10.4172/19485948.1000395

Fibre determination: $2 \mathrm{~g}$ of the sample was weighed accurately into the fibre flask and $100 \mathrm{~mL}$ of $0.255 \mathrm{~N} \mathrm{H}_{2} \mathrm{SO}_{4}$ was added. The mixture was heated under reflux for $1 \mathrm{~h}$ with the heating mantle. The hot mixture was filtered through a fibre sieve cloth. The residue was returned to the fibre flask to which $100 \mathrm{~mL}$ of $(0.313 \mathrm{~N} \mathrm{NaOH})$ was added and heated under reflux for another $1 \mathrm{~h}$. The mixture was filtered through a fibre sieve cloth and $10 \mathrm{~mL}$ of acetone added. The residue was washed with about $50 \mathrm{~mL}$ hot water on the sieve cloth before it was finally transferred into the crucible. The crucible and the residue were oven-dried at $105^{\circ} \mathrm{C}$ overnight to drive off moisture. The oven-dried crucible containing the residue was cooled in a desiccator and weighed to obtain the weight $\mathrm{W}_{1}$. The crucible with weight $\mathrm{W}_{1}$ was transferred to the muffle furnace for ashing at $550^{\circ} \mathrm{C}$ for $4 \mathrm{~h}$. The crucible containing white or grey ash was cooled in the desiccator and weight to obtain $\mathrm{W}_{2}$. The difference $\mathrm{W}_{1}-\mathrm{W}_{2}$ gives the weight of fibre [26].

$$
\% \text { Fibre }=\frac{W_{1}-W_{2}}{\text { Weight of sample }} \times 100
$$

Carbohydrate (CHO): The carbohydrate content was determined by using the formula:

(Moisture content + Crude fat + Crude Protein + Crude Fibre + Ash) - 100 [26].

Phosphorus, sodium, potassium, calcium, copper, zinc, magnesium and iron determination: Phosphorus was determined routinely by the Vanado-Molybdate Colori-Metric method, $0.2 \mathrm{~g}$ of well ground samples of both Mallow leaf and Bitter leaf were weighed into a dried crucible and Put inside a furnace set of $600^{\circ} \mathrm{C}$ and allowed the sample to ash for $2 \mathrm{~h}$. The ash sample was washed by pipetting 10 $\mathrm{mL}$ of INHCL and placed on a hot plate to evaporated to dryness, then another $10 \mathrm{~mL}$ of HCL was added and it was been removed from hot plate. It was allowed to cool and washed into a $10 \mathrm{~mL}$ volumetric flask using filter paper and funnel and it was made with distilled water $\mathrm{H}_{2} \mathrm{O}$ up to $60-100 \mathrm{~mL}$, into a $50 \mathrm{~mL}$ volumetric flask, pipette $10 \mathrm{~mL}$ from 100 $\mathrm{mL}$ of vanadate yellow to it and made it up with distilled $\mathrm{H}_{2} \mathrm{O}$, allowed it to develop for $15 \mathrm{~min}$. The spectrometer was set at $470 \mathrm{~mm}$ and allowed to warm for $15 \mathrm{~min}$ and the standard phosphorus was prepared and read first before the sample [26].

The percentage phosphorus was then calculated from this formula:

$\mathrm{PPm}=$ Meter reading $\times$ Average gradient $\times 1^{\text {st }}$ dilute $\times 2^{\text {nd }}$

Dilution factor divided by weight of sample $\times 1$

Sodium, potassium and calcium: From the washed sample (i.e., $100 \mathrm{~mL}$ ) flame photometer was used to read the level of $\mathrm{Na}, \mathrm{K} \mathrm{Ca}$, after standardized it with is respective minerals. The percentage individual elements were carried out using the formula.

4.4.12 PPM=Copper, zinc and iron: Dilution 1:25 were made for $\mathrm{mg}$ level determination from the washed sample, i.e., $100 \mathrm{~mL}$ flask, after the dilution, it was then read on Atomic Absorption Spectrometer (AAS), after standardized it with $\mathrm{Mg}$ standard. $\mathrm{Cu}, \mathrm{Zn}, \mathrm{Fe}$ were read from the solution that remains in the $100 \mathrm{~mL}$ flask and also read on AAS after standardized with respective elements [26].

They were calculated in parts per million (PPM) by the formula:

$\frac{\text { Meter reaching } \times \text { Average gradient } \times \text { Dilutionfactor }}{\text { Weight of sample }}$

\section{Statistical analysis of data}

The data collected were categorized and analyzed using CoStat 9.0 version and the homogeneity of means was done using Duncan Multiple Range Test (DMRT) at 95\% confidence level (Figure 1).

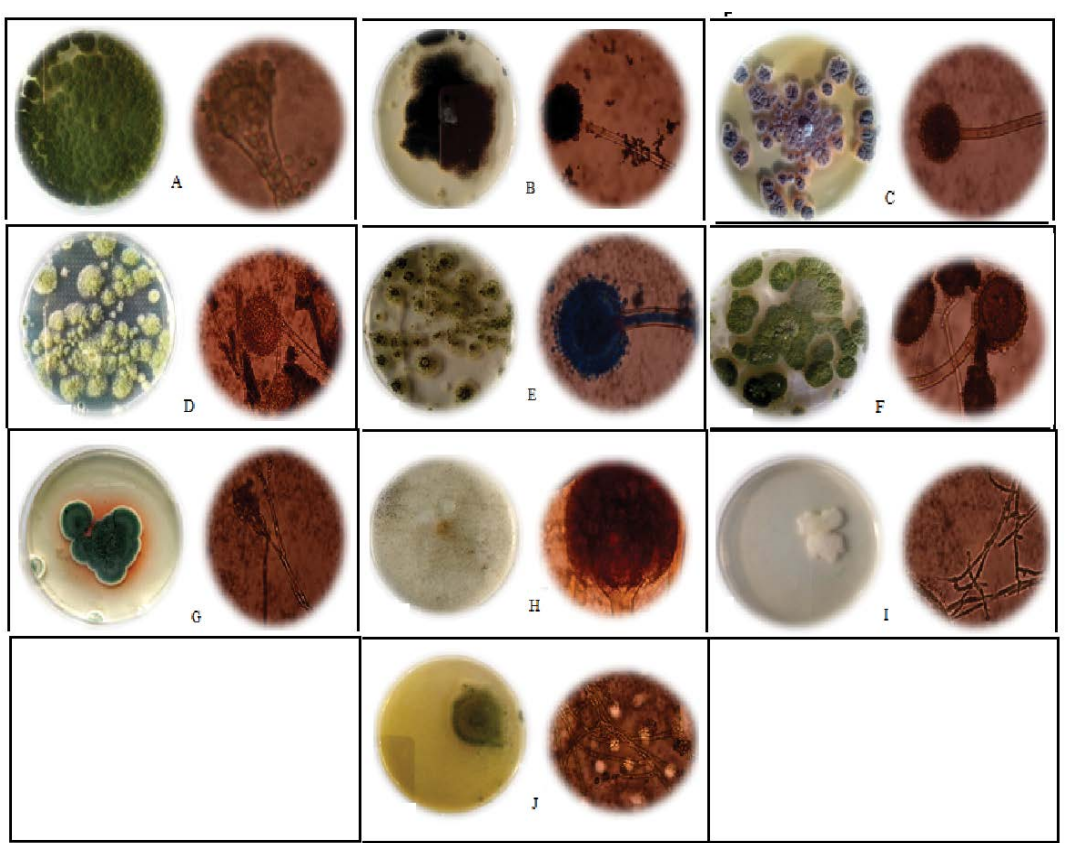

A- Aspergillus flavus, B- A. niger, C- A. tamarii, D- A. parasitius, E- A. fumigatus, F- A. terreus, G- Penicillium chrysogenum, H- Rhizopus nigricans, I- Fusarium compacticum, J- Penicillium oxalicum

Figure 1: Data were represented on tables as means \pm Standard deviation, while qualitative data were described using figures and charts. 
Citation: Segun GJ, Olanrewaju GO, Michael DA, Omolola OO (2018) Effect of Storage Time on Nutrient, Biodeteriorating Fungi and Aflatoxin Contents of Bitter Leaf (Vernonia amygadalina) and JUTE (Corchorus olitorius). J Microb Biochem Technol 10: 49-55. doi: 10.4172/19485948.1000395

\section{Results}

\section{Incidence of biodeteriorating fungi associated with the vegetables samples}

The fungal strains that most commonly isolated from the samples are Aspergillus niger, A. flavus and Rhizopus nigricans with the highest percentage incidences while A. terrus, Penicillium oxalicum, A. tamari, A. fumigatus while A. parasiticus, fusarium oxysporum, penicillium chrysogenum and Trichoderma sp. had the least incidence (Table 1). It was observed that the dominant fungal are those regarded as aflatoxigenic fungal strains due to their ability to produce aflatoxins. Furthermore, the fungi incidence was also observed to be influenced by the sample location, Bodija samples had the most fungi incidence followed by Oja Oba and Moniya samples.

\section{Proximate analysis of Vernonia amygdalina and Corchorus olitorius}

The storage time and location had significant effect on the proximate compositions of the Vernonia amygdalina and Corchorus olitorius samples (Table 2). Apart from the moisture content, the vegetables generally had higher carbohydrate content, followed by crude protein, and fibre while cru fat is the least. The moisture content, crude protein, fibre, ash and fat contents of the vegetables significantly reduced at three month of storage across all the locations as compared to the fresh samples. However, the carbohydrate content of the samples increased at 3 months storage time (Table 2).

Samples of Vernonia amygdalina and Corchorus olitorius collected from Moniya market, Ibadan had the highest crude protein contents of $23.6 \pm 0.14 \%$ and $6.05 \pm 0.07 \%$, respectively while Oja-Oba market had the highest crude fibre content $(10.4 \pm 0.00 \%$ and $1.50 \pm 0.03 \%$, respectively. Crude fat content was detected highest in fresh Corchorus olitorius sample collected from Bodija (0.26 $\pm 0.01 \%)$, Oja-Oba $(0.24 \pm 0.01 \%)$ and Moniya $(0.25 \pm 0.01 \%)$ markets, while Vernonia amygdalina had the highest percentage crude fat in fresh Moniya sample $(9.79 \pm 0.05)$. Highest moisture content was recorded in stored Oja Oba bitter leaf samples $(8.4 \pm$ $0.00 \%)$ and dried Moniya Corchorus olitorius samples ( $8.3 \pm 0.00 \%)$. The highest $\%$ carbohydrate composition was recorded for dried and stored Corchorus olitorius samples collected from Bodija (94.1 $\pm 0.04 \%)$, OjaOba $(93.6 \pm 0.01 \%)$ and Moniya $(93.5 \pm 0.66 \%)$ markets while the stored samples of vernonia amygdalina collected from Bodija market had the highest composition of carbohydrate $(69.3 \pm 0.13 \%)$ followed by Oja Oba $(60.2 \pm 0.05 \%)$ and Moniya (57.9 $\pm 0.12 \%)$.

\section{The mineral analysis of vernonia amygdalina and corchorus olitorius}

The storage time and location also had significant effect on the

\begin{tabular}{|c|c|c|c|c|c|c|c|c|c|c|}
\hline \multirow[b]{2}{*}{ Biodeteriorating fungi } & \multicolumn{5}{|c|}{ Vernonia amygdalina } & \multicolumn{5}{|c|}{ Corchorus olitorius } \\
\hline & Bodija & Oja Oba & Moniya & $\begin{array}{c}\text { Total } \\
\text { Occurrence }\end{array}$ & $\%$ Incidence & Bodija & Oja Oba & Moniya & $\begin{array}{c}\text { Total } \\
\text { Occurrence }\end{array}$ & $\%$ Incidence \\
\hline Fusarium compacticum & 0 & 0 & 0 & 0 & 0 & 0 & 0 & 0 & 0 & 0 \\
\hline F. oxysporum & 0 & 0 & 1 & 0 & 2.2 & 1 & 2 & 1 & 4 & 8.7 \\
\hline Penicillium oxalicum & 2 & 1 & 3 & 6 & 13 & 1 & 2 & 3 & 6 & 13 \\
\hline Penicillium chrysogenum & 0 & 1 & 0 & 1 & 2.2 & 1 & 0 & 1 & 1 & 2.2 \\
\hline Rhizopus nigricans & 3 & 3 & 1 & 7 & 15.2 & 3 & 2 & 2 & 7 & 15.2 \\
\hline Trichoderma spp. & 1 & 0 & 0 & 1 & 2.2 & 0 & 0 & 0 & 0 & 0 \\
\hline Aspergillus tamarii & 0 & 1 & 1 & 2 & 4.3 & 2 & 1 & 0 & 3 & 6.5 \\
\hline Aspergillus terrus & 3 & 3 & 1 & 7 & 10.9 & 3 & 1 & 0 & 4 & 8.7 \\
\hline Aspergillus niger & 1 & 2 & 0 & 3 & 6.5 & 3 & 3 & 2 & 8 & 17.3 \\
\hline Aspergillus parasiticus & 4 & 3 & 2 & 9 & 19.6 & 2 & 1 & 1 & 4 & 8.7 \\
\hline Aspergillus flavus & 1 & 2 & 0 & 3 & 6.5 & 3 & 2 & 2 & 7 & 15.2 \\
\hline Aspergillus fumigatus & 1 & 0 & 1 & 2 & 4.3 & 1 & 0 & 1 & 2 & 4.3 \\
\hline Total & 20 & 14 & 12 & 46 & 100 & 20 & 14 & 12 & 46 & 100 \\
\hline
\end{tabular}

Values are means of tree replicates

Table 1: Percentage incidence of biodeteriorating fungi associated with the selected vegetables.

\begin{tabular}{|c|c|c|c|c|c|c|c|}
\hline \multicolumn{2}{|c|}{ Proximate Composition (\%) } & \multicolumn{3}{|c|}{ Fresh Samples } & \multicolumn{3}{|c|}{ Three months stored samples } \\
\hline Parameters & Sample & Bodija & Oja-Oba & Moniya & Bodija & Oja-Oba & Moniya \\
\hline \multirow[t]{2}{*}{ Crude Protein } & Vernonia amygdalina & $21.4 \pm 0.05 c$ & $22.8 \pm 0.00 b$ & $23.6 \pm 0.14 a$ & $18.5 \pm 0.13 f$ & $19.4 \pm 0.01 \mathrm{e}$ & $20.5 \pm 0.07 d$ \\
\hline & Corchorus olitorius & $5.71 \pm 0.01^{c}$ & $5.91 \pm 0.01^{\mathrm{b}}$ & $6.05 \pm 0.07^{a}$ & $4.29 \pm 0.02^{f}$ & $4.81 \pm 0.01^{d}$ & $4.59 \pm 0.02^{\mathrm{e}}$ \\
\hline \multirow[t]{2}{*}{ Crude Fibre } & Vernonia amygdalina & $9.46 \pm 0.08^{c}$ & $10.4 \pm 0.00^{\mathrm{a}}$ & $8.95 \pm 0.01^{d}$ & $9.81 \pm 0.01^{\mathrm{b}}$ & $8.51 \pm 0.01^{\mathrm{e}}$ & $7.82 \pm 0.03^{f}$ \\
\hline & Corchorus olitorius & $1.54 \pm 0.01^{\mathrm{a}}$ & $1.50 \pm 0.03^{\mathrm{a}}$ & $1.48 \pm 0.01^{b}$ & $1.34 \pm 0.01^{c}$ & $1.30 \pm 0.01^{d}$ & $1.11 \pm 0.01^{\mathrm{e}}$ \\
\hline \multirow[t]{2}{*}{ Crude Fat } & Vernonia amygdalina & $0.11 \pm 0.01^{f}$ & $8.90 \pm 0.00^{\mathrm{b}}$ & $9.79 \pm 0.05^{a}$ & $0.17 \pm 0.00^{e}$ & $7.11 \pm 0.01^{d}$ & $8.60 \pm 0.00^{c}$ \\
\hline & Corchorus olitorius & $0.26 \pm 0.01^{\mathrm{a}}$ & $0.24 \pm 0.01^{\mathrm{a}}$ & $0.25 \pm 0.01^{\mathrm{a}}$ & $0.21 \pm 0.01^{b}$ & $0.20 \pm 0.00^{\mathrm{b}}$ & $0.21 \pm 0.01^{\mathrm{b}}$ \\
\hline \multirow[t]{2}{*}{ Ash } & Vernonia amygdalina & $6.46 \pm 0.02^{\mathrm{b}}$ & $5.96 \pm 0.00^{c}$ & $7.32 \pm 0.25^{\mathrm{a}}$ & $4.25 \pm 0.01^{f}$ & $4.82 \pm 0.02^{\mathrm{e}}$ & $5.23 \pm 0.02^{\mathrm{d}}$ \\
\hline & Corchorus olitorius & $0.13 \pm 0.01^{\mathrm{b}}$ & $0.15 \pm 0.01^{\mathrm{a}}$ & $0.14 \pm 0.00^{\mathrm{a}}$ & $0.10 \pm 0.00^{d}$ & $0.14 \pm 0.00^{\mathrm{a}}$ & $0.11 \pm 0.00^{c}$ \\
\hline \multirow[t]{2}{*}{ Moisture } & Vernonia amygdalina & $10.5 \pm 0.14^{c}$ & $10.7 \pm 0.00 \mathrm{~b}$ & $11.8 \pm 0.10 a$ & $7.0 \pm 0.00 f$ & $8.4 \pm 0.00 d$ & $7.4 \pm 0.00 \mathrm{e}$ \\
\hline & Corchorus olitorius & $10.9 \pm 0.03^{b}$ & $11.2 \pm 0.33 a$ & $10.6 \pm 0.52 c$ & $7.0 \pm 0.00 f$ & $7.5 \pm 0.00 \mathrm{e}$ & $8.3 \pm 0.00 \mathrm{~d}$ \\
\hline \multirow[t]{2}{*}{ Carbohydrate } & Vernonia amygdalina & $62.5 \pm 0.06^{b}$ & $52.1 \pm 0.00 \mathrm{e}$ & $50.4 \pm 0.43 f$ & $69.3 \pm 0.13 a$ & $60.2 \pm 0.05 c$ & $57.9 \pm 0.12 d$ \\
\hline & Corchorus olitorius & $92.4 \pm 0.03 b$ & $92.2 \pm 0.06 b$ & $92.1 \pm 0.10 b$ & $94.1 \pm 0.04 a$ & $93.6 \pm 0.01 a$ & $93.5 \pm 0.66 a$ \\
\hline
\end{tabular}

Values are means of tree replicates, values with the same letter in a column are not significantly different from each other at $p>0.05$

Table 2: The proximate analysis of vegetable samples. 
Citation: Segun GJ, Olanrewaju GO, Michael DA, Omolola OO (2018) Effect of Storage Time on Nutrient, Biodeteriorating Fungi and Aflatoxin Contents of Bitter Leaf (Vernonia amygadalina) and JUTE (Corchorus olitorius). J Microb Biochem Technol 10: 49-55. doi: 10.4172/19485948.1000395

mineral compositions of the Vernonia amygdalina and Corchorus olitorius samples Table 3. Generally, the vegetable samples are richer in Calcium, Potassium and Phosphorus while they contain lower amount of Sodium, Iron, Zinc and Magnesium. It was also noticed that the mineral compositions of the sample decreased at 3 months of storage.

\section{The aflatoxin content of Vernonia amygdalina and Corchorus olitorius}

The aflatoxin analysis conducted on two vegetables (Vernonia amygdalina and Corchorus olitorius) collected from different locations in Nigeria showed that they contain some levels of aflatoxin $B_{1}, B_{2}, G_{1}$ and $G_{2}$ which tend to increase with the storage time (Table 4). Aflatoxin $B_{1}$ and $B_{2}$ were recorded highest in at three month of storage while Aflatoxin $G_{1}$ and Aflatoxin $G_{2}$ were also detected highest in three and two month old samples. It was also observed that the location apart from the storage time also had significant effect on the aflatoxin contents of the sample (Table 4).

\section{Discussion}

This study reveals that storage time had significant effect on the

\begin{tabular}{|c|c|c|c|c|c|c|c|}
\hline \multirow[b]{3}{*}{ Minerals } & \multirow[b]{3}{*}{ Vegetables } & \multicolumn{6}{|c|}{ Mineral Composition (mg/L) } \\
\hline & & \multicolumn{3}{|c|}{ Fresh Vegetable Samples } & \multicolumn{3}{|c|}{ Three (3) Months Old Samples } \\
\hline & & Bodija & Oja-Oba & Moniya & Bodija & Oja-Oba & Moniya \\
\hline \multirow{2}{*}{ Sodium } & Vernonia amygdalina & $6.30 \pm 0.71^{b}$ & $7.40 \pm 0.00^{\mathrm{ab}}$ & $7.93 \pm 0.95^{\mathrm{a}}$ & $4.71 \pm 0.01^{c}$ & $6.71 \pm 0.01^{\mathrm{ab}}$ & $7.30 \pm 0.14^{\mathrm{ab}}$ \\
\hline & Corchorus olitorius & $10.95 \pm 0.49^{a}$ & $11.1 \pm 0.42^{\mathrm{a}}$ & $11.59 \pm 0.16^{a}$ & $8.69 \pm 0.02^{c}$ & $8.30 \pm 0.00^{c}$ & $9.69 \pm 0.01^{\mathrm{b}}$ \\
\hline \multirow{2}{*}{ Potassium } & Vernonia amygdalina & $216.41 \pm 0.01^{c}$ & $217.6 \pm 0.00^{\mathrm{b}}$ & $219.07 \pm 0.52^{\mathrm{a}}$ & $210.29 \pm 0.02^{f}$ & $214.85 \pm 0.07^{d}$ & $212.35 \pm 0.35^{e}$ \\
\hline & Corchorus olitorius & $272.5 \pm 1.27^{\mathrm{bc}}$ & $275.77 \pm 1.89^{a}$ & $274.02 \pm 0.59^{a b}$ & $260.25 \pm 0.21^{\mathrm{d}}$ & $271.0 \pm 0.85^{c}$ & $270.11 \pm 0.01^{c}$ \\
\hline \multirow{2}{*}{ Calcium } & Vernonia amygdalina & $252.15 \pm 0.78^{a}$ & $248.1 \pm 0.00^{\mathrm{b}}$ & $252.05 \pm 0.92^{\mathrm{a}}$ & $248.5 \pm 0.14^{b}$ & $244.8 \pm 0.14^{c}$ & $247.25 \pm 1.20^{\mathrm{b}}$ \\
\hline & Corchorus olitorius & $265.2 \pm 1.27^{\mathrm{b}}$ & $261.2 \pm 0.71^{c}$ & $267.23 \pm 0.38^{a}$ & $258.6 \pm 0.00^{d}$ & $251.2 \pm 0.57^{d}$ & $258.45 \pm 0.07^{e}$ \\
\hline \multirow{2}{*}{ Phosphorus } & Vernonia amygdalina & $220.9 \pm 0.28^{\mathrm{a}}$ & $216.7 \pm 0.00^{c}$ & $216.91 \pm 0.01^{c}$ & $218.55 \pm 0.07^{b}$ & $210.15 \pm 0.07^{e}$ & $211.65 \pm 0.07^{d}$ \\
\hline & Corchorus olitorius & $123.1 \pm 0.42^{\mathrm{e}}$ & $126.85 \pm 1.06^{c}$ & $262.35 \pm 0.78^{a}$ & $120.55 \pm 0.07^{f}$ & $124.61 \pm 0.01^{d}$ & $259.33 \pm 0.52^{b}$ \\
\hline \multirow{2}{*}{ Iron } & Vernonia amygdalina & $3.55 \pm 0.01^{c}$ & $3.72 \pm 0.00^{\mathrm{b}}$ & $3.84 \pm 0.04^{a}$ & $2.71 \pm 0.01^{\mathrm{e}}$ & $2.85 \pm 0.01^{\mathrm{d}}$ & $2.73 \pm 0.01^{\mathrm{e}}$ \\
\hline & Corchorus olitorius & $7.18 \pm 0.11^{\mathrm{b}}$ & $7.73 \pm 0.01^{\mathrm{a}}$ & $7.63 \pm 0.24^{\mathrm{a}}$ & $5.85 \pm 0.01^{\mathrm{e}}$ & $6.11 \pm 0.01^{d}$ & $6.43 \pm 0.02^{\mathrm{c}}$ \\
\hline \multirow{2}{*}{ Zinc } & Vernonia amygdalina & $0.82 \pm 0.01^{\mathrm{e}}$ & $1.44 \pm 0.00^{c}$ & $1.74 \pm 0.01^{\mathrm{a}}$ & $0.77 \pm 0.00^{f}$ & $1.31 \pm 0.01^{d}$ & $1.60 \pm 0.00^{\mathrm{b}}$ \\
\hline & Corchorus olitorius & $4.76 \pm 0.06^{b}$ & $5.16 \pm 0.08^{\mathrm{ab}}$ & $5.52 \pm 0.40^{\mathrm{a}}$ & $3.74 \pm 0.02^{\mathrm{d}}$ & $3.83 \pm 0.01^{\mathrm{cd}}$ & $4.20 \pm 0.00^{c}$ \\
\hline \multirow{2}{*}{ Magnesium } & Vernonia amygdalina & $4.63 \pm 0.01^{\mathrm{a}}$ & $4.57 \pm 0.00^{\mathrm{b}}$ & $4.66 \pm 0.01^{\mathrm{a}}$ & $3.81 \pm 0.01^{c}$ & $3.48 \pm 0.04^{d}$ & $3.24 \pm 0.01^{\mathrm{e}}$ \\
\hline & Corchorus olitorius & $5.44 \pm 0.65^{b c}$ & $5.76 \pm 0.06^{b}$ & $6.67 \pm 0.38^{a}$ & $4.80 \pm 0.00^{\mathrm{cd}}$ & $4.21 \pm 0.01^{d}$ & $4.94 \pm 0.03^{\mathrm{cd}}$ \\
\hline
\end{tabular}

Values are means of tree replicates, values with the same letter in a column are not significantly different from each other at $p>0.05$

Table 3: The mineral composition of vegetable samples.

\begin{tabular}{|c|c|c|c|c|c|c|}
\hline \multirow{2}{*}{ Duration } & \multirow{2}{*}{ Location } & \multirow{2}{*}{ Vegetables } & \multicolumn{4}{|c|}{ Aflatoxin $(\mu \mathrm{g} / \mathrm{kg})$} \\
\hline & & & Aflatoxin $B_{1}$ & Aflatoxin $\mathrm{B}_{2}$ & Aflatoxin $\mathbf{G}_{1}$ & Aflatoxin $\mathbf{G}_{2}$ \\
\hline \multirow{6}{*}{ Fresh } & \multirow{2}{*}{ Bodija Market } & Vernonia amygdalina & $0.0000 \pm 0.000^{g}$ & $0.0010 \pm 0.000^{\mathrm{kl}}$ & $0.0010 \pm 0.000^{d}$ & $0.0000 \pm 0.000^{\mathrm{m}}$ \\
\hline & & Corchorus olitorius & $0.0010 \pm 0.000^{g}$ & $0.0010 \pm 0.000^{\mathrm{kl}}$ & $0.0005 \pm 0.001^{\mathrm{d}}$ & $0.0005 \pm 0.001^{m}$ \\
\hline & \multirow{2}{*}{ Oja-Oba Market } & Vernonia amygdalina & $0.0000 \pm 0.000^{\mathrm{g}}$ & $0.0010 \pm 0.000^{\mathrm{kl}}$ & $0.0010 \pm 0.000^{d}$ & $0.0010 \pm 0.000^{1 \mathrm{~m}}$ \\
\hline & & Corchorus olitorius & $0.0010 \pm 0.000^{g}$ & $0.0010 \pm 0.000^{\mathrm{kl}}$ & $0.0010 \pm 0.000^{d}$ & $0.0010 \pm 0.000^{\mathrm{Im}}$ \\
\hline & \multirow{2}{*}{ Moniya Market } & Vernonia amygdalina & $0.0010 \pm 0.000^{g}$ & $0.0020 \pm 0.000^{\mathrm{jk}}$ & $0.0020 \pm 0.000^{\text {cd }}$ & $0.0010 \pm 0.000^{\mathrm{lm}}$ \\
\hline & & Corchorus olitorius & $0.0010 \pm 0.000^{g}$ & $0.0020 \pm 0.000^{\mathrm{jk}}$ & $0.0010 \pm 0.000^{d}$ & $0.0020 \pm 0.000^{\mathrm{kl}}$ \\
\hline \multirow{6}{*}{ One month } & \multirow{2}{*}{ Bodija Market } & Vernonia amygdalina & $0.0100 \pm 0.000^{f}$ & $0.0200 \pm 0.000^{i}$ & $0.0010 \pm 0.000^{d}$ & $0.0010 \pm 0.000^{\mathrm{Im}}$ \\
\hline & & Corchorus olitorius & $0.0200 \pm 0.000^{e}$ & $0.0300 \pm 0.000^{d}$ & $0.0025 \pm 0.001^{\mathrm{cd}}$ & $0.0020 \pm 0.000^{\mathrm{kl}}$ \\
\hline & \multirow{2}{*}{ Oja-Oba Market } & Vernonia amygdalina & $0.0010 \pm 0.000^{g}$ & $0.0030 \pm 0.000^{j}$ & $0.0010 \pm 0.000^{d}$ & $0.0025 \pm 0.001^{k}$ \\
\hline & & Corchorus olitorius & $0.0100 \pm 0.000^{f}$ & $0.0010 \pm 0.000^{\mathrm{kl}}$ & $0.0020 \pm 0.000^{\mathrm{cd}}$ & $0.0035 \pm 0.001^{j}$ \\
\hline & \multirow{2}{*}{ Moniya Market } & Vernonia amygdalina & $0.0010 \pm 0.000^{g}$ & $0.0020 \pm 0.000^{\mathrm{jk}}$ & $0.0010 \pm 0.000^{d}$ & $0.0030 \pm 0.000^{\mathrm{jk}}$ \\
\hline & & Corchorus olitorius & $0.0010 \pm 0.000^{g}$ & $0.0030 \pm 0.000^{j}$ & $0.0010 \pm 0.000^{d}$ & $0.0020 \pm 0.000^{\mathrm{kl}}$ \\
\hline \multirow{6}{*}{ Two month } & \multirow{2}{*}{ Bodija Market } & Vernonia amygdalina & $0.0200 \pm 0.000^{e}$ & $0.0220 \pm 0.000^{h}$ & $0.0040 \pm 0.000^{\mathrm{bcd}}$ & $0.0050 \pm 0.000^{i}$ \\
\hline & & Corchorus olitorius & $0.0285 \pm 0.002^{b}$ & $0.0330 \pm 0.000^{c}$ & $0.0060 \pm 0.000^{\mathrm{bcd}}$ & $0.0060 \pm 0.000^{g h}$ \\
\hline & \multirow{2}{*}{ Oja-Oba Market } & Vernonia amygdalina & $0.0290 \pm 0.001^{\mathrm{b}}$ & $0.0345 \pm 0.001^{\mathrm{b}}$ & $0.0030 \pm 0.000^{\mathrm{bcd}}$ & $0.0050 \pm 0.000^{i}$ \\
\hline & & Corchorus olitorius & $0.0240 \pm 0.001^{d}$ & $0.026 \pm 0.0014^{f}$ & $0.0050 \pm 0.000^{\text {cd }}$ & $0.0065 \pm 0.001^{g}$ \\
\hline & \multirow{2}{*}{ Moniya Market } & Vernonia amygdalina & $0.0210 \pm 0.000^{\mathrm{e}}$ & $0.0230 \pm 0.000^{g h}$ & $0.0025 \pm 0.001^{\mathrm{cd}}$ & $0.0035 \pm 0.001^{j}$ \\
\hline & & Corchorus olitorius & $0.0200 \pm 0.000^{\mathrm{e}}$ & $0.0240 \pm 0.000^{g}$ & $0.0135 \pm 0.015^{\mathrm{a}}$ & $0.0055 \pm 0.001^{\mathrm{hi}}$ \\
\hline \multirow{6}{*}{ Three month } & \multirow{2}{*}{ Bodija Market } & Vernonia amygdalina & $0.029 \pm 0.0014^{b}$ & $0.0305 \pm 0.001^{d}$ & $0.0075 \pm 0.001^{\mathrm{abcd}}$ & $0.0110 \pm 0.000^{d}$ \\
\hline & & Corchorus olitorius & $0.036 \pm 0.0014^{a}$ & $0.0405 \pm 0.001^{\mathrm{a}}$ & $0.0085 \pm 0.001^{a b c}$ & $0.0120 \pm 0.000^{c}$ \\
\hline & \multirow{2}{*}{ Oja-Oba Market } & Vernonia amygdalina & $0.036 \pm 0.0014^{a}$ & $0.041 \pm 0.0014^{a}$ & $0.0055 \pm 0.001^{\mathrm{abcd}}$ & $0.0075 \pm 0.001^{\mathrm{e}}$ \\
\hline & & Corchorus olitorius & $0.028 \pm 0.000^{\mathrm{bc}}$ & $0.0335 \pm 0.002^{\mathrm{bc}}$ & $0.0070 \pm 0.000^{\mathrm{bcd}}$ & $0.0095 \pm 0.001^{f}$ \\
\hline & \multirow{2}{*}{ Moniya Market } & Vernonia amygdalina & $0.0265 \pm 0.001^{c}$ & $0.0280 \pm 0.000^{\mathrm{e}}$ & $0.009 \pm 0.0014^{\mathrm{abc}}$ & $0.0135 \pm 0.001^{\mathrm{b}}$ \\
\hline & & Corchorus olitorius & $0.0245 \pm 0.001^{d}$ & $0.0265 \pm 0.001^{f}$ & $0.0105 \pm 0.001^{\mathrm{ab}}$ & $0.0155 \pm 0.001^{\mathrm{a}}$ \\
\hline
\end{tabular}

Values are means of tree replicates, values with the same letter in a column are not significantly different from each other at $p>0.05$

Table 4: The aflatoxin concentration of vegetable samples. 
Citation: Segun GJ, Olanrewaju GO, Michael DA, Omolola OO (2018) Effect of Storage Time on Nutrient, Biodeteriorating Fungi and Aflatoxin Contents of Bitter Leaf (Vernonia amygadalina) and JUTE (Corchorus olitorius). J Microb Biochem Technol 10: 49-55. doi: 10.4172/19485948.1000395

nutrient and aflatoxin compositions of two selected vegetables Vernonia amygdalina and Corchorus olitorius, the most dominantly associated fungal stains with the dried samples of these vegetables are identified as Aspergillus flavus, Aspergillus niger, Aspergillus terreus, Aspergillus tamarii, Aspergillus parasiticus, Aspergillus fumigatus, Penicillium chrysogenum and Rhizopus nigricans. The presence of these organisms is not surprising as their source could be from soil, dust or the vegetable themselves at the point of harvest however, many of these fungi belongs to the group of aflatoxin producing fungi; this observation is in conformity to the reports of that reported many Aspergillus species as the common storage fungi affecting dried tomato and pumpkin leaf [27,28]. Aguoru et al. [29] also reported Aspergillus fungi as part of the major contaminants in the environment which causes spoilage of foods and many agricultural produce [29].

It was observed in this study that the aflatoxin contaminations in samples increased with concurrent fungal incidence in the dried vegetables especially at the third month of storage as earlier observed by who reported progressive increase in species of fungi in stored sundried plantain chips and coco yam chips respectively [30,31]. This also follow the reduction in the proximate composition of the samples which could be due to the deteriorating activities by the fungi as substrate for metabolism similar to the observation, when they worked on some indigenous green leafy vegetables [32-34]. The quantity of crude protein, fat, crude fibre and ash in both samples decreased with an increasing storage period except carbohydrate which increased with the storage period. This could be as a result of reduction in moisture content during storage as suggested, who also reported that carbohydrate in Moringa leaves increased on air drying compared to the fresh form [32]. Generally, both vegetables were rich in Potassium, Calcium, Phosphorus and Sodium over Iron, Zinc and Magnesium, but their nutrient composition varied cross location, this is could be as a result of different factors such as geographic locations, or soil fertility or its fecundity $[35,36]$.

The fresh samples were observed to contain lower aflatoxin contaminations as compared to the stored samples; this is in agreement with the report of who reported less aflatoxins contents in fresh pumpkin leaves and Spinaches between the range $0.07-7.32 \mu \mathrm{g} / \mathrm{kg}$ as compared to the stored samples [37-39]. However, aflatoxins $B_{1}$ and $B_{2}$ were detected higher than the aflatoxins $G_{1}$ and $G_{2}$ in the samples, which are generally higher in stored samples that fresh ones, this could be due to the fact that the phytochemicals such as flavonoids, saponins and alkaloids present on the fresh plants are more potent as antifungal biocide than in dried samples [40,41]. 27 found $60 \%$ of dried red chili pepper contaminated with up to $19.45 \mu \mathrm{g} / \mathrm{kg}$ aflatoxins but detected no aflatoxin in fresh Baobab and Okra leaves.

Several abiotic factors influence the growth of moulds on dried vegetables; they are relative humidity and temperature together with the moisture content of the product and storage conditions [42-44]. The main factor responsible mycotoxin production is the interaction between the fungi, its host, and the environmental condition as the concentrations of the aflatoxin vary with the location [45]. The level of fungi infestations can be compounded by insect damage, stress condition at pre-harvest, harvest and post-harvest stages of vegetable production [44]. Other possible source of fungi infestation can result from inappropriate handling and storage methods often associated with poor hygiene and also the methods of processing, packaging and storage can also have great effect on fungal contamination. The climatic and environmental conditions are highly favorable for the propagation of fungi especially the genera Aspergillus spp., Penicillium spp., Mucor spp. and Rhizopus spp. that produce and release a lot of spores [46]. From this study, it was observed that dried vegetable can also serve as substrates for aflatoxin producing fungi and these products are exposed to environmental condition that favors the fungal growth and development. It has been reported that ingestion of foods that are contaminated with high concentration of mycotoxins can lead to much greater health risks [47].

\section{Conclusion}

It was observed from this study that storage time can affect the nutritional value of dried bitter leaf and jute vegetables and as well may increase their aflatoxin contaminations due to associated fungi. However from this study it was observed that the aflatoxin concentrations in the studied vegetables were generally within the permissive level of $20 \mu \mathrm{g} /$ $\mathrm{kg}$ for adults as stipulated in most countries. The presence of aflatoxin in these vegetables necessitates the involvement of good agricultural practices, hygienic processing and handling with good storage practices and facilities. There is also a need for central risk assessment evaluation on all commodities to be consumed to prevent fungal growth in stored vended food and this could also be achieved through the application of strict hygienic measures during processing and storage periods.

\section{References}

1. Apeh DO, Ochal DO, Adejumo A, Muhammad HL, Saidu AN (2016) Mycotoxicological concerns with sorghum, millet and sesame in northern Nigeria. J Anal Bioanal Tech 7:336.

2. Jonathan SG, Adeniyi MA, Asemoloye MD (2015) Fungal biodeterioration aflatoxin contamination and nutrient value of 'aadun'. Researcher 7: 26-32.

3. Jonathan Segun G, Bello Tunde S and Asemoloye Michael D (2017) Food values, spoilage moulds and aflatoxin detection in 'Attiéké' (A Cassava Fermented Product). J Microb Biochem Technol 9: 244-248.

4. Candlish AA, Aidoo KE, Smith JE, Pearson SM (2000) A limited survey of aflatoxin and fumonisin in retail maize-based products in the UK using immunoassay detection. Mycotoxin Res 16: 2-8.

5. Ramakrishna N, Lacey J, Candlish AA, Smith JE, Goodbrand LA (1990) Monoclonal antibodies based enzyme linked immunoscorbant assay of aflatoxin B, T-2 toxin and ochratoxin A in barley. J Assoc Off Anal Chem 73 71-76.

6. Jonathan SG, Oghodero O, Asemoloye MD (2016) Incidence of molds in treated and untreated drinking water of selected local governments in Ibadan south-western Nigeria. Res Rev Biosci 11: 108-118.

7. Milanez TV, M. Sabino M, Lamardo LC (1995) A comparison of two methods for the determination of ochratoxin $A$ in green coffee beans. Revista de Microbiologia 26: 79-82.

8. Ramesh VB, Siruguri V (2003) Food safety in food security and food trade. In: Mycotoxin food safety risk in developing countries: Food Agri Environ, pp: 16-20.

9. Fezekas B, Tar A, Kovascs M (2005) Aflatoxin and ochratoxin a content of spices in Hungary. Food Addict Contam 9: 856-863.

10. Kabelitz L, Sievers H (2004) Contaminants of medicinal and food herbs with a view of EU regulations. Innov Food Tech 1: 25-27.

11. Giryn H, Szteke B (1995) Estimation of Altenaria mycotoxins in some raw or processed fruit and vegetables. Roczniki Panstwowego Zakladu Higieny 46 133.

12. Bankole SA, Adebanjo A (2003) Review of mycotoxins in food in West Africa: Current situation and possibilities of controlling it. Afr J Biotech 2: 254-263.

13. Muhammad S, Shehu K, Amusa NA (2004) Survey of the market diseases and aflatoxin contamination of tomato (Lycopersicon esculentum MILL) fruits in Sokoto north western Nigeria. Nutri Food Sci 34: 72-76.

14. Baiyewu RA, Amusa NA (2007) Biochemical changes in pawpaw fruits (VAR ISOLO, JS22 and HOMESTEAD) infected with fungi. Biosci Res Commun 11: 257-261. 
Citation: Segun GJ, Olanrewaju GO, Michael DA, Omolola OO (2018) Effect of Storage Time on Nutrient, Biodeteriorating Fungi and Aflatoxin Contents of Bitter Leaf (Vernonia amygadalina) and JUTE (Corchorus olitorius). J Microb Biochem Technol 10: 49-55. doi: 10.4172/19485948.1000395

15. Mandeel OA (2005) Fungal contamination of some imported spices. Mycopathologia 159: 291-298.

16. Bankole SA, Ogunsanwo BM, Osho A, Adewuyi GO (2006) Fungal contamination and aflatoxin B1 of 'egusi' melon seeds in Nigeria. Food Control 17:814-818.

17. Aregheore EM (1998) Chemical composition, nutritive value and preference of goats for bitter leaf (Vernonia amygdalina) as a browse plant. Sci Agric Bohemica 29: 213-221.

18. Daodu MO, Babayemi OJ (2009) Utilization of some edge-row plants as forage in Nigeria. Pak J Nutr 8: 1269-1274.

19. Igile GO, Olesezk W, Burda S, Jurzysta M (1995) Nutritional assessment of Vernonia amygdalina leaves in growing mice. J Agric Food Chem 43: 2162 2166.

20. Odofin AJ, Oladiran JA, Oladipo JA, Wuya EP (2011) Determination of evapotranspiration and crop coefficients for bush okra (Corchorus olitorius) in a sub-humid area of Nigeria. Afr J Agric Res 6: 3949-3953.

21. Fondio L, Grubben GJH, Dento OA (2004) Corchorus olitorius L. In: Plant Resources of Tropical Africa 2. Vegetables. PROTA Foundation, Wageningen, Netherlands/Backhuys. Leiden, Netherlands/CTA, Wageningen, Netherlands.

22. Schippers RR (2000) African Indigenous Vegetables: An overview of the cultivated species. Natural Resources Institute, Acp-Eu Technical Centre for agricultural and rural cooperation, Chatham, United Kingdom.

23. Jimoh KO, Kolapo AL (2008) Mycoflora and aflatoxin production in market samples of some selected Nigerian foodstuffs. Res J Microb 3:169-174.

24. Malgorzata R, Loannou M (2012) Teaching resources from microbiology laboratory. Hals Oer Project De Montfort University.

25. Association of Official Analytical Chemists (AOAC) (2006) Natural toxins. In official methods of analysis of AOAC International. AOAC. International, Gaithersburg 18: 1-22.

26. Association of Official Analytical Chemists (AOAC) (2005). Association of Official Analytical Chemists. Official Methods of Analysis of the Association of Analytical Chemists International, Gathersburg, MD U.S.A. 18: 1-38.

27. Makun HA, Mailafiya CS, Saidi AA, Onwuike BC, Onwubiko MU (2012) A preliminary survey of aflatoxin in fresh and dried vegetables in Minna, Nigeria. Afr J Food Sci Tech 3: 268-272.

28. Suleiman MS, Nuntah LC, Muhammad HL, Mailafiya SC, Makun HA (2017) Fungi and aflatoxin occurrence in fresh and dried vegetables marketed in Minna, Niger State, Nigeria. J Plant Biochem Physiol 5:176.

29. Aguoru CU, Okoli BE, Olasan JO (2014) Phytogeography of the genus Sesamum L. (Pedaliaceae) in Nigeria. West Tropical Africa Scient. Crop Sci 3: 115-122.

30. Fagbohun ED, Abegunde OK, David OM (2010) Nutritional and mycoflora changes during storage of plantain chips and the health implications. J Agri Biotech Sust Dev 2: 61-65.
31. Lawal OU, Fagbohun ED, Olajide HA (2012) Nutritive value and mycoflora of sun dried cocoyam chips during storage. Inter J Agro Agri Res 2: 1-7.

32. Olayemi F, Foline A, Awagu FE, Bamishaiye IE (2011) Comparative Analysis of the nutritional composition of three different drying methods of Moringa leaves. Inter J Appl Agri Res 6: 131- 138

33. Otitoju GTO, Ene-Obong HN, Otitoju O (2014) Macro and micro nutrient composition of some indigenous green leafy vegetables in south-east zone Nigeria. J Food Process Technol 5: 389.

34. Jonathan, G, Ajayi I, Omitade Y (2011a) Nutritional compositions, fungi and aflatoxins detection in stored 'gbodo' fermented (Dioscorea rotundata) and 'elubo ogede' fermented (Musa parasidiaca) from south western Nigeria. Afr $J$ Food Sci 5: 105-110.

35. Tewe OO, Lutaladio N (2004) Cassava for livestock feed in sub-Saharan Africa Rome, Italy: FAO.

36. Mensah JK, Okoli RI, Ohaju-Obodo JO, Eifediyi K (2008) Phytochemical nutritional and medical properties of some leafy vegetables consumed by Edo people of Nigeria. Afr J Biotech 7: 2304-2309.

37. Lugauskas A, Raudoniene $V$, Sveistyte $L$ (2005) Toxin producing micromycetes on imported products of plant origin. Ann Agric Environ Med 12: 109-118.

38. Nagmus S, Mubarik A, Zahida P, Amber I, Abbas B (2009) Screening of mycotoxins in wheat, fruits and vegetables grown in Sindh, Pakistan. Pak J Bot 41: 337-341.

39. Suleiman MS, Nuntah LC, Muhammad HL, Mailafiya SC, Makun HA (2017) Fungi and aflatoxin occurrence in fresh and dried vegetables marketed in Minna, Niger State, Nigeria. J Plant Biochem Physiol 5: 176.

40. Abosi AO, Raseroka BH (2003) In vivo antimalarial activity of Vernonia amygdalina. Br J Biomed Sci 60: 89-91.

41. Efuntoye MO (1996) Fungi associated with herbal drug plants during storage Mycopathologia 136: 115-118.

42. Jonathan SG, Okoawo EE, Asemoloye MD (2016) Fungi and aflatoxin contamination of sausage rolls. Inter J Sci Res 4: 99-104.

43. Pitt JI, Hocking AD, Glenn DR (1983) An improved medium for the detection of Aspergillus flavus and A. parasiticus. J App Microbiol 54: 109-114.

44. Asemoloye MD, Jonathan SG, Sadaf R, Habiba ZO, koawo EE, et al. (2017) Incidence and chemical implications of aflatoxin in street-vended foods. In Aflatoxin-control, analysis, detection and health risks, InTech.

45. Jonathan SG, Adeniyi MA, Asemoloye MD (2016) Nutrient value, funga biodeterioration and aflatoxin contamination of suya spices novel Nigerian indigenous snacks. Hindawi-Scientifica.

46. Domsch KH, Gams W, Anderson TK (1980) Compendium of soil fungi, Academic Press, London, p: 857.

47. Williams JH, Phillips TD, Jolly PE, Stiles JK, Jolly CM, et al. (2004) Human aflatoxicosisin developing countries: A review of toxicology, exposure, potentia health consequences and interventions. Am J Clin Nutr 80: 1106-1122. 